\title{
KEPUTUSAN DIREKSI BADAN USAHA MILIK NEGARA (BUMN) SEBAGAI KEPUTUSAN TATA USAHA NEGARA
}

\author{
(Decree of The Board of Directors of State Owned Enterprises (BUMN) \\ as Decision of State Administration)
}

\author{
Ade Irawan Taufik \\ Pusat Analisis dan Evaluasi Hukum Nasional Badan Pembinaan Hukum Nasional \\ e-mail: adeirawantaufik@gmail.com
}

Naskah diterima: 22 mei 2020; revisi: 17 November 2020; disetujui: 18 November 2020

\begin{abstract}
Abstrak
Ketidakpastian apakah Badan Usaha Milik Negara (BUMN) merupakan Badan Tata Usaha Negara atau bukan serta ketidakpastian apakah BUMN merupakan badan hukum privat atau badan hukum publik, berakibat pada ketidakjelasan ke lembaga peradilan mana gugatan diajukan apabila terdapat orang atau badan yang dirugikan akibat keputusan yang dikeluarkan oleh BUMN tersebut. Ketidakpastian tersebut juga berakibat pada pemahaman yang berbeda di antara hakimhakim di Pengadilan Tata Usaha Negara (PTUN), yakni terdapat hakim di PTUN yang dapat menerima BUMN sebagai pihak tergugat, namun ada pula yang menolak jika pihak tergugat adalah BUMN. Berdasarkan hal tersebut, permasalahan yang dibahas dalam tulisan ini yakni, apakah BUMN merupakan badan tata usaha negara dan apakah keputusan yang dikeluarkan oleh direksi atau manajerial BUMN merupakan suatu keputusan tata usaha negara sehingga menjadi kewenangan absolut dari Pengadilan Tata Usaha Negara? Dengan menggunakan penelitian yuridis normatif disimpulkan tidak semua BUMN atau Direksi BUMN dapat digeneralisir sebagai badan atau pejabat tata usaha negara, begitu pula tidak semua keputusan dari direksi atau manajerial BUMN dianggap sebagai keputusan tata usaha negara. Hal ini dikarenakan entitas hukum BUMN memiliki dua sisi, yakni entitas hukum publik dan entitas hukum perdata,sehingga apakah suatu keputusan direksi atau manajerial BUMN dapat digugat di Pengadilan Tata Usaha Negara seharusnya dilihat secara kasuitis.

Kata Kunci: Badan Usaha Milik Negara, Badan Tata Usaha Negara, kompetensi absolut
\end{abstract}

\begin{abstract}
The uncertainty whether a State-Owned Enterprises (BUMN) is a State-Administrative Body or not and whether a BUMN is a private legal entity or a public legal entity, results in the ambiguity to which judicial institution should a lawsuit is filed if any person or entity suffered losses due to a decision issued by BUMN. This uncertainty also inflicted in a diverse perception among judges in the State Administrative Court (PTUN), that is, some judges in PTUN can accept BUMN as defendants, while others refuse on the occasion that the defendants are BUMN. Based on the aforementioned, the problem in this paper is, whether BUMN is a state administrative body and whether the decision issued by the directors or administrator of the BUMN is a state administrative decision so that it becomes the absolute authority of the State Administrative Court? By using normative juridical research, it is concluded that not every BUMN or BUMN Directors can be generalized as state administrative bodies or officials, as well as not every decisions of BUMN directors or managerial are considered as state administrative decisions. This is because BUMN legal entities have two sides, namely public legal entities and civil legal entities, so whether a directors or managerial decisions of BUMN can be charged in the State Administrative Court should be viewed case by case.
\end{abstract}

Keywords: State-Owned Enterprises, State-Administrative Body, absolute authority 


\section{A. Pendahuluan}

Ketidakpastian apakah Badan Usaha Milik Negara (BUMN) merupakan Badan Tata Usaha Negara atau bukan serta ketidakpastian apakah BUMN merupakan badan hukum privat atau badan hukum publik, berakibat pada ketidakjelasan ke lembaga peradilan mana gugatan diajukan apabila terdapat orang atau badan yang dirugikan akibat keputusan yang dikeluarkan oleh BUMN tersebut. Ketidakpastian tersebut juga berakibat pada pemahaman yang berbeda di antara hakimhakim di PTUN, yakni terdapat hakim di PTUN yang dapat menerima BUMN sebagai pihak tergugat, namun ada pula yang menolak jika pihak tergugat adalah BUMN.

BUMN sebagai salah satu pelaku ekonomi dalam sistem perekonomian nasional, berperan strategis menghasilkan barang dan/atau jasa yang diperlukan dalam rangka mewujudkan kemakmuran masyarakat dan juga sebagai pelaksana pelayanan publik. ${ }^{1}$ Dilihat dari perannya tersebut, maka BUMN selain berusaha untuk mencari keuntungan juga melakukan usaha untuk kemanfaatan umum. $^{2}$ Berdasarkan perannya tersebut, terdapat dua bentuk BUMN, yaitu: Perusahaan Perseroan (Persero) yang bertujuan memupuk keuntungan dan Perusahaan Umum (Perum) yang bertujuan untuk melaksanakan usaha sebagai implementasi kewajiban pemerintah guna menyediakan barang dan jasa tertentu untuk memenuhi kebutuhan masyarakat. ${ }^{3}$

Dalam menjalankan usahanya dan mencapai tujuan dibentuknya BUMN, Direksi pada BUMN bertanggungjawab penuh atas pengurusan BUMN untuk tercapainya kepentingan dan tujuan BUMN serta mewakili BUMN baik di dalam maupun diluar pengadilan. ${ }^{4}$ Bentuk pelaksanaan dari pengurusan BUMN tersebut salah satunya diwujudkan melalui keputusan-keputusan yang dibuat oleh Direksi (atau level manajerial lainya), ${ }^{5}$ yang di dalam setiap pengambilan keputusan/tindakan, Direksi harus mempertimbangkan segala risiko usaha. ${ }^{6}$ Namun pada kenyataannya, terdapat keputusan-keputusan direksi BUMN yang dinilai merugikan orang atau badan sehingga rentan adanya sengketa dan gugatan yang diajukan terhadap keputusan yang dikeluarkan oleh direksi BUMN.

Permasalahannya adalah lembaga peradilan mana yang berwenang untuk memeriksa dan memutus perkara gugatan terhadap keputusan direksi tersebut, apakah Pengadilan Negeri atau Pengadilan Tata Usaha Negara. Hal ini mengingat masih terdapatnya perdebatan terkait kelembagaan BUMN, apakah BUMN termasuk lembaga negara atau badan usaha privat. Perdebatan ini wajar mengingat tidak dapat lepasnya intervensi negara secara politik pada BUMN. ${ }^{7}$ Oleh

\footnotetext{
Lebih lanjut lihat Penjelasan Umum Undang-Undang No. 19 Tahun 2003 tentang Badan Usaha Milik Negara (UU BUMN).

2 Lebih lanjut lihat Pasal 2 UU BUMN.

3 Lebih lanjut lihat Pasal 9, Pasal 12, dan Pasal 36 UU BUMN.

4 Lebih lanjut lihat Pasal 1 angka 9 dan Pasal 5 UU BUMN jo. Pasal 1 angka 7 dan Pasal 26 Peraturan Pemerintah No. 45 Tahun 2005 tentang Pendirian, Pengurusan, Pengawasan dan Pembubaran Badan Usaha Milik Negara.

5 Dalam tulisan ini tidak hanya terkait dengan keputusan yang dikeluarkan oleh Direksi, namun juga keputusankeputusan yang dikeluarkan oleh level manajer yang diberikan kewenangan oleh direksi untuk dapat mengambil keputusan pada hal-hal tertentu.

6 Lebih lanjut lihat Pasal 25 ayat (1) Peraturan Menteri BUMN No. PER-01/MBU/2011 tentang Penerapan Tata Kelola Perusahaan Yang Baik Pada BUMN.

7 Terdapat penilaian bahwa intervensi negara tersebut dapat membatasi ruang gerak BUMN dalam berusaha,
} 
karena itu permasalahan kompetensi dalam memeriksa dan memutus perkara terhadap keputusan direksi, menjadi penting untuk dikaji.

Ketidakjelasan terkait kompetensi absolut tersebut dapat terlihat dari adanya permohonan uji materi terhadap Pasal 1 angka 7, angka 8 dan angka 9 Undang-Undang No. 51 Tahun 2009 tentang Perubahan Kedua Atas Undang-Undang Nomor 5 Tahun 1986 tentang Peradilan Tata Usaha Negara ke Mahkamah Konstitusi (MK) dengan nomor perkara 55/PUU-XV/2017. Dalam perkara tersebut, Pemohon merupakan pensiunan pegawai BUMN di Perusahaan Negara Pengangkutan Penumpang Djakarta (sekarang disebut Perum PPD), merasa dirugikan karena tidak dibayarkannya hak untuk mendapatkan uang pensiun bulanan sebagaimana dimaksud dalam peraturan perundangan yang berlaku bagi Pegawai Negeri Sipil dan tidak mendapatkan pengakuan dan jaminan sebagai Pensiunan Pegawai Perusahaan Negara Pengangkutan Penumpang Djakarta karena para Pemohon dianggap sebagai Pekerja BUMN padahal para Pemohon tidak diangkat dengan Perjanjian Kerja Bersama di bidang ketenagakerjaan. Sebelumnya kerugian yang diderita pemohon telah diajukan ke PTUN, namun gugatan para Pemohon tersebut kemudian diputuskan tidak dapat diterima dengan pertimbangan yang pada pokoknya menyatakan bahwa permasalahan para
Pemohon bukan merupakan kewenangan PTUN karena karyawan Perum PPD adalah sebagai pegawai BUMN maka segala permasalahan yang timbul dalam Perum PPD mengenai ketenagakerjaan merupakan kewenangan dari Perselisihan Hubungan Industrial. Atas permohonan tersebut MK memutuskan menolak permohonan pemohon tersebut.

Selain perkara tersebut, terdapat pula perkara di PTUN yang melibatkan BUMN sebagai Tergugat. Terdapat beberapa putusan PTUN yang diputus dengan NO (niet ontvankelijke verklaard) yakni putusan yang menyatakan bahwa gugatan tidak dapat diterima karena mengandung cacat formil. ${ }^{8}$ Contoh, Putusan Pengadilan Tinggi Tata Usaha Negara Surabaya No. 165/B/2019/ PT.TUN.SBY yang menguatkan Putusan Pengadilan Tata Usaha Negara Surabaya No. 165/G/2018/PTUN.SBY yang mengabulkan eksepsi Tergugat tentang kompetensi absolut. Namun ada pula yang putusan yang menerima dan mengabulkan gugatan Penggugat dengan tergugatnya adalah BUMN, sebagaimana terdapat dalam Putusan Tata Usaha Negara Bandung No. 74/G/2014/PTUN-BDG.

Dari beberapa kasus tersebut di atas dan beberapa contoh perkara lainnya menarik untuk dikaji apakah BUMN merupakan badan tata usaha negara dan apakah keputusan yang dikeluarkan oleh direksi atau manajerial BUMN merupakan suatu keputusan tata

sehingga perannya dalam memberikan pemasukan kepada negara melalui pajak dan deviden tidak maksimal terlaksana. Lebih lanjut lihat Agus Adhari, "Eksistensi BUMN sebagai Korporasi yang Dikuasai Negara," Jurnal Hukum Bisnis dan Investasi, Vol. 7 (1), 2015, hlm. 27-36.

8 Menurut Yayah Harahap, gugatan yang diputuskan dengan NO (niet ontvankelijke verklaard) adalah: 1) gugatan yang ditandatangani kuasa berdasarkan surat kuasa yang tidak memenuhi syarat yang digariskan Pasal 123 ayat (1) HIR; 2) Gugatan tidak memiliki dasar hukum; 3) Gugatan error in persona dalam bentuk diskualifikasi atau plurium litis consortium; 4) Gugatan mengandung cacat obscuur libel, ne bis in idem, atau melanggar yurisdiksi (kompetensi) absolut atau relatif. Lebih lanjut lihat Yahya Harahap, Hukum Acara Perdata (Jakarta: Sinar Grafika, 2006), hlm. 811. 
usaha negara sehingga menjadi kewenangan absolut dari Pengadilan Tata Usaha Negara?

\section{B. Metode Penelitian}

Dalam penelitian ini, digunakan metode penelitian yuridis normatif. ${ }^{9}$ Metode ini digunakan karena diperlukan untuk mengindentifikasi dan menelaah peraturan perundang-undangan yang terkait dengan BUMN dan juga tata usaha negara. Dari kedua bidang peraturan tersebut dianalisis korelasi yang saling mengatur diantara kedua bidang tersebut. Kemudian untuk mendapatkan data implementasi pengaturan kedua bidang tersebut, penulis menelusuri, mengindentifikasi serta menganalisis putusan-putusan pengadilan dalam menafsirkan peraturan kedua bidang tersebut terhadap kasus-kasus yang terkait dengan BUMN dalam bidang tata usaha negara. Selain itu, untuk menguatkan argumentasi penulis dalam menjawab permasalahan, penulis juga mengutip teori-teori hukum dan pendapatpendapat hukum dari tulisan-tulisan yang terkait dengan permasalahan yang ditelliti.

\section{Pembahasan}

\section{Konsepsi dan Karakteristik BUMN Berdasarkan UU BUMN}

Merujuk pada ketentuan Pasal 1 angka 1 UU BUMN, disebutkan bahwa yang dimaksud dengan BUMN adalah "badan usaha yang seluruh atau sebagian besar modalnya dimiliki oleh negara melalui penyertaan secara langsung yang berasal dari kekayaan negara yang dipisahkan." Definisi BUMN tersebut hanya menjelaskan terkait asal modal dari BUMN, tidak menjelaskan terkait bentuk dan jenis usahanya. Mengenai bentuk dari BUMN dapat diketahui dari ketentuan Pasal 9, yakni BUMN terdiri dari Perusahaan Perseroan (Persero) dan Perusahaan Umum (Perum). Persero menurut ketentuan Pasal 1 angka 2 UU BUMN adalah "BUMN yang berbentuk perseroan terbatas yang modalnya terbagi dalam saham yang seluruh atau paling sedikit 51\% (lima puluh satu persen) sahamnya dimiliki oleh Negara Republik Indonesia yang tujuan utamanya mengejar keuntungan," sedangkan Perum menurut ketentuan Pasal 1 angka 4 UU BUMN adalah "BUMN yang seluruh modalnya dimiliki negara dan tidak terbagi atas saham, yang bertujuan untuk kemanfaatan umum berupa penyediaan barang dan/atau jasa yang bermutu tinggi dan sekaligus mengejar keuntungan berdasarkan prinsip pengelolaan perusahaan."

Berdasarkan definisi Persero dan Perum di atas, maka terdapat 2 perbedaan utama dari kedua bentuk BUMN tersebut, yakni dari sisi jumlah dan jenis modal yang dimiliki negara dan dari sisi tujuan dibentuknya. Dalam Persero, modalnya terbagi atas saham dan dimiliki minimal 51\% (lima puluh satu persen) 
oleh negara dan bertujuan untuk mencari keuntungan, sedangkan Perum, modalnya tidak terbagi saham, dan seluruh dimiliki negara dan, bertujuan untuk kemanfaatan umum dan juga keuntungan (keuntungan bukan tujuan utama). Namun demikian secara umum, maksud dan tujuan dibentuknya BUMN adalah: "a) memberikan sumbangan bagi perkembangan perekonomian nasional pada umumnya dan penerimaan negara pada khususnya; b) mengejar keuntungan; c) menyelenggarakan kemanfaatan umum berupa penyediaan barang dan/atau jasa yang bermutu tinggi dan memadai bagi pemenuhan hajat hidup orang banyak; d) menjadi perintis kegiatan-kegiatan usaha yang belum dapat dilaksanakan oleh sektor swasta dan koperasi; e) turut aktif memberikan bimbingan dan bantuan kepada pengusaha golongan ekonomi lemah, koperasi, dan masyarakat. ${ }^{10}$

\section{Konsepsi BUMN sebagai 'Kepanjangan Tangan' Pemerintah}

Berdasarkan maksud dan tujuan pendirian BUMN sebagaimana tersebut di atas, terdapat salah satu tujuan pendirian BUMN yang perlu dicermati, yakni menyelenggarakan kemanfaatan umum berupa penyediaan barang dan/atau jasa yang bermutu tinggi dan memadai bagi pemenuhan hajat hidup orang banyak. Atas dasar tersebut BUMN melaksanakan penugasan Pemerintah melalui mekanisme Public Service Obligation (PSO). ${ }^{11}$ Salah satu bentuk PSO yaitu penyaluran komoditas bersubsidi. Beberapa komoditas bersubsidi yang ditugaskan ke BUMN, antara lain: 1) BBM tertentu (premium, minyak tanah, solar dan LPG 3 KG) oleh Pertamina; 2) listrik oleh PT. PLN, (3) pupuk oleh PT. Pupuk Indonesia; 4) beras untuk rakyat miskin oleh Perum Bulog; 5) benih oleh PT Sang Hyang Seri dan PT Pertani. Selain itu BUMN juga ditugaskan untuk sebagai penyedia angkutan bersubsidi yang dilaksanakan oleh PT Pelni dan PT Kereta Api Indonesia. Kemudian BUMN juga sering diberikan 'penugasan khusus' untuk melaksanakan program strategis pemerintah, antara lain penyediaan energi listrik melalui pembangunan pembangkit listrik, konversi dari minyak tanah ke gas, penyaluran Bantuan Lanngsung Tunai oleh PT. Pos. ${ }^{12}$

Kegiatan PSO dan 'penugasan khusus' tersebut menjadikan BUMN terkesan sebagai 'kepanjangan tangan' dari pemerintah, sehingga timbul juga kesan BUMN sebagai 'instansi pemerintah'. Kesan tersebut juga menimbulkan permasalahan bagaimana pembagian tugas, kewenangan dan tanggungjawab atas pelaksanaan PSO dan Penugasan Khusus. Penugasan khusus pada BUMN mengakibatkan BUMN berkedudukan 'ganda': pertama, sebagai pengemban tugas pemerintahan terkait PSO yang terhadapnya berlaku hukum administrasi; dan kedua, sebagai instrumen pencari keuntungan atau sumber pendapatan (income) negara yang berlaku hukum privat/hukum perseroan. Kedudukan ganda ini mengakibatkan

10 Lebih lanjut lihat ketentuan Pasal 2 UU BUMN.

11 PSO di dalam UU BUMN disebut sebagai "Kewajiban Pelayanan Umum" sebagaimana diatur di dalam Pasal 66 UU BUMN. Di dalam pasal tersebut diatur bahwa "Pemerintah dapat memberikan penugasan khusus kepada BUMN untuk menyelenggarakan fungsi kemanfaatan umum dengan tetap memperhatikan maksud dan tujuan kegiatan BUMN".

12 Kementerian BUMN, "Rencana Startegis Kementerian BUMN 2015-2019", diunduh dari www.bumn.go.id, diakses tanggal 17 November 2019. 
pertanggungjawaban ganda pula pada Direksi BUMN. Pada satu sisi Direksi BUMN harus bertanggung jawab sebagai pengguna anggaran/barang yang bertanggung jawab atas pengelolaan uang Negara, pada sisi yang lain Direksi BUMN harus bertanggung jawab sebagai pengurus BUMN yang bertanggung jawab atas pengelolaan harta kekayaan BUMN. Pertanggungjawaban ganda Direksi BUMN ini terkait pada dua pendanaan/anggaran yang berbeda. Pertama, adalah pendanaan terkait dengan pelaksanaan PSO yang tidak termasuk kekayaan BUMN. Pendanaan ini disebut penyertaan Negara yang tidak dijadikan modal BUMN. Untuk itu pertangggungjawabannya berlaku mekanisme APBN, yang untuk BUMN diatur UU BUMN, UU Keuangan Negara, UU Perbendaharaan Negara dan UU Pemeriksaan Pengelolaan dan Tanggung Jawab Keuangan Negara. Untuk itulah BPK berwenang melakukan audit keuangan BUMN. Kedua, adalah pendanaan yang disebut dengan penyertaan modal Negara, yang berbentuk saham-saham yang masuk dalam kekayaan BUMN. Dalam kedudukannya sebagai pengguna anggaran APBN, Direksi BUMN harus bertanggung jawab menurut hukum publik/hukum administrasi/hukum keuangan negara. Sanksi-sanksi pelanggaran Direksi BUMN dalam kedudukannya sebagai pengguna anggaran adalah sanksi pidana, administratif dan perdata. ${ }^{13}$

Merujuk peraturan perundang-undangan dapat diketemukan bahwa BUMN, khususnya Perum, memiliki karakteristik sebagai 'kepanjangan tangan' dari Pemerintah, yakni dengan masuknya Menteri sebagai Organ Perum. ${ }^{14}$ Kewenangan Menteri merupakan kewenangan yang tertinggi dibandingkan dengan Direksi dan Dewan Pengawas. Menteri dapat mengangkat dan memberhentikan Direksi dan Dewan Pengawas. ${ }^{15}$ Kemudian segala kebijakan kebijakan pengembangan yang akan dilakukan Direksi harus diusulkan terlebih dahulu ke Menteri. ${ }^{16}$ Dari karakteristik ini jelas sekali 'kepanjangan tangan' Pemerintah dalam Perum. Menteri mempunyai kekuasaan untuk menentukan jalannya Perum, Direksi tidak lebih dari pelaksana dari kebijakan pengembangan Perum yang telah ditetapkan oleh Menteri.

Dari ketentuan Pasal 37 dan 38 UU BUMN tersebut terlihat BUMN sebagai 'kepanjangan tangan' pemerintah, sehingga BUMN menjadi 'kedudukan ganda'. Hal inilah yang menyebabkan BUMN rentan terhadap gugatan yang diajukan orang atau badan hukum terhadap keputusan direksi yang dinilai merugikan, namun apakah keputusan yang dikeluarkan oleh Direksi atau manajerial BUMN dapat dikategorikan sebagai keputusan tata usaha negara.

'Kepanjangan tangan' Pemerintah yang diemban oleh BUMN semakin jelas bila merujuk pada Putusan Mahkamah Konstitusi Nomor: 48/PUU-XI/2013. Dalam pertimbangan hukum putusan tersebut, $M K$ berpendapat bahwa: "BHMN PT, Badan Usaha Milik Negara (BUMN), Badan Usaha Milik Daerah (BUMD), atau nama lain, atau yang lebih khusus lagi yang menyelenggarakan amanah konstitusional dalam Pasal 31, Pasal 
32, dan Pasal 33 UUD 1945 adalah sebagai kepanjangan $\operatorname{tangan}^{17}$ dari negara dalam menjalankan sebagian dari fungsinegara untuk mencapai tujuan negara, yaitu mencerdaskan kehidupan bangsa, atau memajukan kesejahteraan umum. Oleh karena itu, dari perspektif modal badan hukum, atau nama lain yang sejenis, yang menjalankan sebagian dari fungsi negara tersebut, keuangan yang menjadi modalnya sebagian atau seluruhnya berasal dari keuangan negara. Dari perspektif ini dan fungsi badan hukum dimaksud tidak dapat sepenuhnya dianggap sebagai badan hukum privat." Kemudian dinyatakan pula oleh MK bahwa: "Mahkamah juga telah mempertimbangkan bahwa BHMN PT atau BUMN/BUMD merupakan kepanjangan tangan pemerintah dalam menyelenggarakan fungsi pemerintahan dalam arti luas."

Menurut penulis hal ini tergantung dari posisi direksi atau managerial BUMN ketika dia mengeluarkan keputusannya. Dalam posisinya sebagai pengemban tugas pemerintahan terkait Kewajiban Pelayanan Umum atau PSO, pengguna anggaran APBN langsung dan juga urusan pemerintah lainnya, dimana BUMN mengembang sebagai 'kepanjangan tangan' Pemerintah, maka terhadap BUMN tersebut berlaku hukum administrasi, sehingga dapat digugat di pengadilan tata usaha negara. Tidak semua keputusan yang dikeluarkan oleh Direksi atau manajerial BUMN dapat dikategorikan sebagai keputusan tata usaha negara, dalam hal ini perlu dilihat dari tiaptiap keputusan yang dikeluarkan apakah memenuhi karakteristik atau unsur dari suatu keputusan tata usaha negara.

\section{Konsepsi Kedudukan BUMN Sebagai Badan Hukum Perdata}

Seperti yang telah diuraikan di atas, BUMN merupakan badan usaha yang seluruh atau sebagian besar modalnya dimiliki oleh negara melalui penyertaan secara langsung yang berasal dari kekayaan negara yang dipisahkan. ${ }^{18}$ Definisi BUMN tersebut hanya menjelaskan terkait asal modal dari BUMN, tidak menjelaskan terkait bentuk dan jenis usahanya. Mengenai bentuk dari BUMN dapat diketahui dari ketentuan Pasal 9, yakni BUMN terdiri dari Perusahaan Perseroan (Persero) dan Perusahaan Umum (Perum). Persero adalah "BUMN yang berbentuk perseroan terbatas yang modalnya terbagi dalam saham yang seluruh atau paling sedikit $51 \%$ (lima puluh satu persen) sahamnya dimiliki oleh Negara Republik Indonesia yang tujuan utamanya mengejar keuntungan,"19 sedangkan Perum adalah "BUMN yang seluruh modalnya dimiliki negara dan tidak terbagi atas saham, yang bertujuan untuk kemanfaatan umum berupa penyediaan barang dan/atau jasa yang bermutu tinggi dan sekaligus mengejar keuntungan berdasarkan prinsip pengelolaan perusahaan." 20

Berdasarkan definisi Persero dan Perum di atas, maka terdapat dua perbedaan utama dari kedua bentuk BUMN tersebut, yakni dari sisi jumlah dan jenis modal yang dimiliki negara dan dari sisi tujuan dibentuknya. Dalam Persero, modalnya terbagi atas saham dan dimiliki minimal 51\% (lima puluh satu persen) oleh negara dan bertujuan untuk mencari keuntungan, sedangkan Perum, modalnya

17 Garis bawah oleh Penulis.

18 Lebih lanjut lihat ketentuan Pasal 1 angka 1 UU BUMN.

19 Lebih lanjut lihat ketentuan Pasal 1 angka 2 UU BUMN.

20 Lebih lanjut lihat ketentuan Pasal 1 angka 4 UU BUMN. 
tidak terbagi saham, dan seluruh dimiliki negara dan, bertujuan untuk kemanfaatan umum dan juga keuntungan (keuntungan bukan tujuan utama). ${ }^{21}$

Oleh karena BUMN berbentuk 'persero' maka terhadapnya berlaku segala ketentuan dan prinsip-prinsip yang berlaku bagi perseroan terbatas sebagaimana diatur dalam Undang-Undang Nomor 40 Tahun 2007 tentang Perseroan Terbatas (selanjutnya disebut UU PT). ${ }^{22}$ Berlakunya prinsip-prinsip dan ketentuan UU PT terhadap BUMN Persero maka menjadikan BUMN Persero sebagai badan hukum, karena prinsipnya Perseroan Terbatas (PT) merupakan badan hukum yang melakukan kegiatan usaha dengan modal dasar yang seluruhnya terbagi dalam saham. ${ }^{23}$

Prinsip dasar suatu badan hukum adalah memiliki hak-hak melakukan suatu perbuatan sebagai manusia, memiliki kekayaan sendiri, serta digugat dan menggugat di depan Pengadilan. ${ }^{24}$ Selain itu PT sebagai badan hukum memiliki beberapa ciri substantif yang melekat pada dirinya, yakni: terbatasnya tanggung jawab, perpetual succession; memiliki kekayaan sendiri; memiliki kewenangan kontraktual serta dapat menuntut dan dituntut atas nama dirinya sendiri. ${ }^{25}$ Menurut Otto von Gierke, badan hukum itu menjadi suatu 'verbandpersoblich keit' yaitu suatu badan yang membentuk kehendaknya dengan perantaraan alat-alat atau organ-organ badan tersebut misalnya anggota-anggotanya atau pengurusnya seperti manusia yang mengucapkan kehendaknya dengan perantaraan mulutnya atau dengan perantaraan tangannya jika kehendak tersebut ditulis di atas kertas. Apa yang mereka (organen) putuskan adalah kehendak dari badan hukum. Berfungsinya badan hukum dipersamakan dengan fungsinya manusia, karena itu dapat disimpulkan bahwa tiap-tiap perkumpulan atau perhimpunan orang adalah badan hukum. Badan Hukum Tidak Mungkin dimiliki badan hukum lain, tetapi dikuasai dalam bentuk yang dikehendaki undangundang.

Arifin P. Soeria Atmadja menegaskan bahwa status hukum Persero (BUMN) adalah murni badan hukum perdata, demikian pula hubungan usaha diatur menurut hukum perdata serta tidak memiliki fasilitas negara. Nomenklatur yang berlaku pada lembaga pemerintah sama sekali tidak berlaku pada Persero, termasuk di dalamnya status hukum pegawai Persero termasuk direksinya adalah pegawai swasta biasa. ${ }^{26}$ Dalam wujudnya sebagai badan hukum perdata tersebut, BUMN dapat dikatakan personifikasi negara, oleh karenanya BUMN harus siap pada 
resiko usaha berupa kerugian. ${ }^{27}$ Hekinus Manao sebagaimana dikutip oleh Jamin Ginting menyatakan bahwa pemahaman keuangan negara dalam BUMN atau BUMD sering diidentikkan dengan aset pemerintah sehingga seluruh piutang maupun utang BUMN/BUMD adalah piutang maupun utang dari pemerintah, padahal pemahaman yang benar adalah kekayaan yang dipisahkan oleh pemerintah pada BUMN/BUMD adalah bagian dari kekayaan negara. Kekayaan negara tersebut adalah sebesar "modal yang disetor" atau "perubahannya" (net equity). ${ }^{28}$

Berdasarkan uraian di atas, maka konsep BUMN yang dimaksud adalah BUMN yang berbentuk Persero. Oleh karenanya BUMN berbentuk persero merupakan badan hukum perdata biasa karena terhadapnya berlaku prinsip-prinsip dan ketentuan dalam UU PT. Selain itu BUMN sebagai badan hukum perdata memiliki konsekuensi bahwa segala tindakan dan pengaturannya adalah tindakan hukum perdata dan dengan pengaturan hukum perdata.

Ditinjau dari 'Agency Theory', pengelolaan BUMN sejalan dengan agensifikasi apabila dilihat dari penekanannya terhadap tata kelola yang lebih memerhatikan prinsip efisiensi dan efektivitas. Oleh karena itu, teori agensi sangat mendukung kinerja BUMN. Agency theory merupakan teori yang menjelaskan tentang hubungan kontraktual antara pihak yang mendelegasikan pengambilan keputusan tertentu

(principal/pemilik/pemegang saham) ${ }^{29}$ dengan pihak yang menerima pendelegasian tersebut (agent/direksi/ manajemen). Menurut Misahardi Wilamarta dalam Ridwan Khairandy dan Camelia Malik, teori agensi memberikan pandangan yang terbaru terhadap good corporate governance (GCG), yaitu para pendiri perseroan dapat membuat perjanjian yang seimbang antara principal (pemegang saham) dengan agen (direksi). Teori ini muncul setelah fenomena terpisahnya kepemilikan perusahaan dengan pengelolaan, terutama pada perusahaanperusahaan besar yang modern. ${ }^{30}$

Namun demikian, pengelompokan BUMN sebagai 'instansi pemerintah' atau bukan tergantung dari jenis, format, dan operasionalisasi dari BUMN itu sendiri itu. Pada dasarnya BUMN merupakan badan hukum perdata yang tidak mempunyai kewenangan publik. Kekayaan negara yang menjadi modal dalam bentuk saham dari badan usaha tersebut tidak lagi merupakan kekayaan negara, tetapi telah berubah status hukumnya menjadi kekayaan badan usaha tersebut. Demikian pula kedudukan hukum pejabat pemerintah yang duduk sebagai pemegang saham swasta lainnya. Imunitas publiknya sebagai penguasa yang memiliki otoritas tidak berlaku lagi, dan kepadanya tunduk dan berlaku sepenuhnya hukum privat, meskipun saham perusahaan tersebut seratus persen milik negara. ${ }^{31}$

27 Panji Anoraga, BUMN, Swasta dan Koperasi Tiga Pelaku Ekonomi (Semararang: Pustaka Jaya, 1994), hlm. 2122 dalam Dian Puji N. Simatupang, Paradoks Rasionalitas: Perluasan Ruang Lingkup Keuangan Negara dan Implikasinya Terhadap Kinerja Keuangan Pemerintah (Jakarta: Badan Penerbit FH UI, 2011), hlm. 233.

28 Jamin Ginting, "Pengertian Merugikan Keuangan Negara dalam Tindak Pidana Korupsi", Jurnal Law Review Fakultas Hukum UPH, Vol. VI, No. 2, November 2006, hlm. 31.

29 Ridwan Khaerandy dan Camelia Malik, Good Corporate Governance (Yogyakarta: Total Media, 2007), hlm. 16.

30 Henny Juliani, "Pertanggungjawaban Direksi Bumn Terhadap Perbuatan Yang Mengakibatkan Kerugian Keuangan Negara", Jurnal Masalah - Masalah Hukum, Jilid 45 No. 4, Oktober 2016, hlm. 299-306.

31 Ridwan HR, Hukum Administrasi Negara (Jakarta: Raja Grafindo, 2007), hlm. 87. 


\section{Konsepsi Badan/Pejabat Tata Usaha Negara dan Keputusan Tata Usaha Negara}

Berdasarkan ketentuan Pasal 1 angka 8 Undang-Undang No. 51 Tahun 2009 tentang Perubahan Kedua Atas Undang-Undang No. 5 Tahun 1986 tentang Peradilan Tata Usaha Negara, yang dimaksud dengan Badan atau Pejabat Tata Usaha Negara adalah badan atau pejabat yang melaksanakan urusan pemerintahan berdasarkan peraturan perundang-undanganyang berlaku.Sedangkan di dalam Undang-Undang No. 30 Tahun 2014 tentang Administrasi Pemerintahan (UU AP) disebutkan bahwa yang dimaksud dengan Badan dan/atau Pejabat Pemerintahan adalah "unsur yang melaksanakan Fungsi Pemerintahan, baik di lingkungan pemerintah maupun penyelenggara negara lainnya." 'Fungsi Pmerintahan' itu sendiri didefinisikan sebagai fungsi dalam melaksanakan Administrasi Pemerintahan yang meliputi fungsi pengaturan, pelayanan, pembangunan, pemberdayaan, dan pelindungan. ${ }^{32}$

Dari definisi Badan atau Pejabat Tata Usaha Negara tersebut, dalam sengketa Tata Usaha Negara unsur yang lebih ditonjolkan adalah fungsi suatu Badan atau Pejabat Tata Usaha Negara itu sendiri dan dari mana kewenangannya itu didapat, artinya bahwa sepanjang suatu Badan atau Pejabat Tata Usaha Negara mendapatkan kewenangan berdasarkan peraturan perundang-undangan yang berlaku, dan kewenangan tersebut adalah urusan yang melaksanakan suatu kegiatan pemerintahan yang didapatkan melalui pelimpahan kewenangan, maka Badan atau Pejabat Tata Usaha Negara dimaksud telah memenuhi kriteria sebagaimana dimaksud Pasal 1 angka 8 dan Pasal 1 angka 12 Undang-Undang Nomor 51 Tahun 2009, sehingga dapat dijadikan Tergugat ${ }^{33}$ dalam di Peradilan Tata Usaha Negara.

Berdasarkan ketentuan Pasal 1 angka 9 Undang-Undang No. 51 Tahun 2009 tentang Perubahan Kedua Atas Undang-Undang No. 5 Tahun 1986 tentang Peradilan Tata Usaha Negara, yang dimaksud dengan Keputusan Tata Usaha Negara adalah "suatu penetapan tertulis yang dikeluarkan oleh badan atau pejabat tata usaha negara yang berisi tindakan hukum tata usaha negara yang berdasarkan peraturan perundang-undangan yang berlaku, yang bersifat konkret, individual, dan final, yang menimbulkan akibat hukum bagi seseorang atau badan hukum perdata." Kemudian di dalam Pasal 2 Undang-Undang No. 9 Tahun 2004 tentang Perubahan Atas Undang-Undang No. 5 Tahun 1986 tentang Peradilan Tata Usaha Negara ditegaskan bahwa yang tidak termasuk dalam pengertian Keputusan Tata Usaha Negara, yakni: a) Keputusan Tata Usaha Negara yang merupakan perbuatan hukum perdata; b) Keputusan Tata Usaha Negara yang merupakan pengaturan yang bersifat umum; c) Keputusan Tata Usaha Negara yang masih memerlukan persetujuan; d) Keputusan Tata Usaha Negara yang dikeluarkan berdasarkan ketentuan Kitab Undang-Undang Hukum Pidana dan Kitab Undang- Undang Hukum Acara Pidana atau peraturan perundang-undangan lain 
yang bersifat hukum pidana; e) Keputusan Tata Usaha Negara yang dikeluarkan atas dasar hasil pemeriksaan badan peradilan berdasarkan ketentuan peraturan perundangundangan yang berlaku; f) Keputusan Tata Usaha Negara mengenai tata usaha Tentara Nasional Indonesia; g) Keputusan Komisi Pemilihan Umum baik di pusat maupun di daerah mengenai hasil pemilihan umum.

Keputusan Tata Usaha Negara menurut UU AP disebut pula sebagai 'Keputusan Administrasi Pemerintahan' atau 'Keputusan Administrasi Negara'. Pengertian Keputusan Administrasi Pemerintahan yang dimaksud dalam UU AP yakni "ketetapan tertulis yang dikeluarkan oleh Badan dan/atau Pejabat Pemerintahan dalam penyelenggaraan pemerintahan". ${ }^{34}$ Dari kedua pengertian Keputusan tersebut, terlihat rumusan pengertian Keputusan Administrasi Pemerintahan mempunyai lingkup yang lebih luas dan tidak memiliki unsur yang bersifat "bersifat konkret, individual, dan final serta menimbulkan akibat hukum bagi seseorang atau badan hukum perdata".

Namun demikian berdasarkan Pasal 87 UU AP ditegaskan bahwa dengan berlakunya UU AP, maka Keputusan Tata Usaha Negara sebagaimana dimaksud dalam UndangUndang Nomor 5 Tahun 1986 tentang Peradilan Tata Usaha Negara sebagaimana telah diubah dengan Undang-Undang Nomor 9 Tahun 2004 dan Undang-Undang Nomor 51 Tahun 2009 harus dimaknai sebagai:

a. penetapan tertulis yang juga mencakup tindakan faktual;

b. Keputusan Badan dan/atau Pejabat Tata Usaha Negara di lingkungan eksekutif, legislatif, yudikatif, dan penyelenggara negara lainnya;

c. berdasarkan ketentuan perundangundangan dan AUPB;

d. bersifat final dalam arti lebih luas;

e. Keputusan yang berpotensi menimbulkan akibat hukum; dan/atau

f. Keputusan yang berlaku bagi Warga Masyarakat.

Berlakunya UU AP yang mengubah makna Keputusan Tata Usaha Negara berakibat pada kompetensi dari Peradilan Tata Usaha Negara. Hal ini tergambar dalam Surat Edaran Mahkamah Agung No. 4 Tahun 2016 tanggal 9 Desember 2016 tentang Pemberlakuan Rumusan Hasil Rapat Pleno Kamar Mahkamah Agung Tahun 2016 Sebagai Pedoman Pelaksanaan Tugas Bagi Pengadilan. Dalam butir E tentang Rumusan Hukum Tata Usaha Negara disebutkan bahwa adanya perubahan paradigma beracara di Peradilan Tata Usaha Negara setelah berlakunya Undang-Undang Nomor 30 Tahun 2014 tentang Administrasi Pemerintahan (UU AP), maka Kompetensi Peradilan Tata Usaha Negara meliputi:

a. Berwenang mengadili perkara berupa gugatan dan permohonan;

b. Berwenang mengadili perbuatan melanggar hukum oleh pemerintah, yaitu perbuatan melanggar hukum yang dilakukan oleh pemegang kekuasaan pemerintahan (Badan dan/atau Pejabat Pemerintahan) yang biasa disebut dengan onrechtmatige overheidsdaad (OOD);

c. Keputusan tata usaha negara yang sudah diperiksa dan diputus melalui upaya banding administrasi menjadi kewenangan Pengadilan Tata Usaha Negara.

34 Lebih lanjut lihat ketentuan Pasal 1 angka 7 Undang-Undang No. 30 Tahun 2014 tentang Administrasi Pemerintahan. 
Kemudian terkait Subjek Gugatan/ Permohonan berdasarkan Pasal 53 ayat (1), Pasal 1 angka 9 Undang-Undang Peradilan Tata Usaha Negara (Undang-Undang Peratun), dan Pasal 21 Undang-Undang Administrasi Pemerintahan:

1) Penggugat/Pemohon: Orang atau Badan Hukum Perdata, dan Badan/Pejabat Pemerintahan.

2) Tergugat/Termohon: Badan/Pejabat Pemerintahan.

Selanjutnya terkait Objek Gugatan/ Permohonan, meliputi:

a. Objek gugatan pada Pengadilan Tata Usaha Negara meliputi:

1) Penetapan tertulis dan/atau tindakan faktual.

2) Dikeluarkan oleh Badan/Pejabat Pemerintahan.

3) Diterbitkan berdasarkan peraturan perundang-Undangan dan/atau asasasas umum pemerintahan yang baik (keputusan tata usaha negara dan/ atau Tindakan yang bersumber dari kewenangan terikat atau kewenangan bebas).

4) Bersifat:

- Konkret-Individual (contoh: keputusan izin mendirikan bangunan, dsb).

- Abstrak-Individual (contoh: keputusan tentang syarat-syarat pemberian perizinan, $\mathrm{dsb}$ ).

- Konkret-Umum (contoh: keputusan tentang penetapan upah minimum regional, dsb).

5) Keputusan Tata Usaha Negara dan/ atau Tindakan yang bersifat Final dalam arti luas yaitu Keputusan Tata Usaha Negara yang sudah menimbulkan akibat hukum meskipun masih memerlukan persetujuan dari instansi atasan atau instansi lain (contoh: perizinan tentang fasilitas penanaman modal oleh Badan Koordinasi Penanaman Modal (BKPM), Izin Lingkungan, dsb).

6) Keputusan Tata Usaha Negara dan/atau Tindakan yang berpotensi menimbulkan akibat hukum (contoh: LHP Badan Pengawas Keuangan dan Pembangunan (BPKP), dsb).

b. Keputusan Tata Usaha Negara dan/atau Tindakan Fiktif Positif.

c. Keputusan Lembaga Aparat Pengawasan Intern Pemerintah (APIP) permohonan pengujian penyalahgunaan wewenang sebagaimana dimaksud dalam Pasal 21 Undang-Undang Nomor 30 Tahun 2014 tentang Administrasi Pemerintahan.

\section{Konsepsi Keputusan Direksi BUMN Dalam Lingkup Keputusan Tata Usaha Negara}

Pendekatan fungsional yang sudah dikembangkan oleh Peradilan Tata Usaha Negara, meskipun tidak selalu konsisten, merupakan sebuah bentuk inovasi hukum yang sebenarnya berharga untuk ditindaklanjuti oleh pembuat UU AP, namun kemudian dikesampingkan oleh pembuat UU AP. Pengecualian BUMN sebagai subjek tergugat dalam sengketa TUN justru menambah ketidak jelasan dari kekaburan status entitas hukum seperti BUMN, apakah dapat digolongkan sebagai "badan publik negara" atau "badan publik non negara" atau lembaga hibrida yang merupakan perwujudan dari "lembaga publik negara sekaligus sebagai lembaga publik non negara". 
Indroharto menyatakan kapan kegiatan atau keputusan hukum suatu BUMN merupakan kegiatan pelaksanaan urusan pemerintahan dapat dikembangkan melalui yurisprudensi Peratun. Namun ia menekankan bahwa pelaksanaan wewenang pemerintahan menurut hukum publik yang dilakukan oleh suatu BUMN itu pada dasarnya serupa dengan pelaksanaan wewenang pemerintahan yang dilaksanakan oleh Badan atau Jabatan TUN. ${ }^{35}$ Pernyataan Indroharto yang menyatakan bahwa BUMN bisa digugat di PTUN dengan syarat tergantung pada jenis keputusan yang dikeluarkan oleh PTUN dan bukan pada jenis BUMN tersebut. ${ }^{36}$ Pandangan Indroharto tersebut dapat diterima namun terdapat aspek penting yang terlewati, yakni jenis perusahaan tetap penting untuk menentukan apakah pegawainya adalah pegawai negeri sipil atau bukan. Hal ini menentukan apakah bila terjadi konflik, para pegawai ini harus menggugat BUMN ke PTUN atau Panitia Penyelesaian Perselisihan Perburuhan. ${ }^{37}$

Entitas hukum BUMN memiliki dua sisi, yakni entitas hukum publik dan entitas hukum perdata, artinya meskipun BUMN adalah badan hukum perdata namun dalam skala ruang pengertian tertentu implikasi tindakantindakan hukumnya dalam bidang pelayanan publik menjadi sebuah isu hukum publik tersendiri, dalam beberapa hal, BUMN dapat bertindak seolah seperti otoritas administrasi yang melaksanakan kewenangan publik masing-masing. ${ }^{38}$
Permasalahan entitas hukum BUMN ini telah lama disadari oleh Mahkamah Agung, dalam Pedoman Khusus No. 052/Td.TUN/ III/1992 disebutkan bahwa dua dari empat jenis BUMN dapat digugat di PTUN, yakni: Perum, yang meliputi Perumka Perum PLN dan PDAM serta Pertamina. Selain itu, para pegawai yang telah disahkan sebagai pegawai negeri sipil berdasarkan statute terpisah dapat mengajukan gugatan ke PTUN bila terjadi konflik dengan atas mereka.

Meskipun MA telah mengeluarkan pedoman tersebut, namun dalam praktiknya terdapat pemahaman yang berbeda di antara hakim-hakim di PTUN, yakni yang dapat menerima BUMN sebagai pihak tergugat namun ada pula yang menolak jika tergugat adalah BUMN. Hal ini dapat terlihat dari beberapa contoh kasus yang akan penulis uraikan sebagai berikut:

\section{Putusan Pengadilan Tinggi Tata Usaha Negara Surabaya No. 165/B/2019/ PT.TUN.SBY \\ Kasus Posisi:}

Para Pihak: PT. Bromo Panuluh Steel (Pembanding/Penggugat) dan Manajer PT. PLN Distribusi Jawa Timur Area Sidoarjo (Terbanding/Tergugat);

Putusan: menguatkan Putusan Pengadilan Tata Usaha Negara Surabaya No. 168/G/2018/ PTUN.SBY tanggal 11 April 2019, yang amarnya berbunyi:

- Dalam Penundaan: Menolak Permohonan Penggugat tentang penundaan pelaksanaan surat manager PT. PLN

\footnotetext{
35 Indroharto, Usaha Memahami Undang-Undang tentang Peradilan tata Usaha Negara (Jakarta: Pustaka Sinar Harapan, 2000), hlm. 168-169 dikutip dalam Enrico Simanjuntak, Hukum Acara Peradilan Tata Usaha Negara: Transformasi dan Refleksi (Jakarta: Sinar Grafika, 2018), hlm. 91.

36 Adriaan W. Bedner, Peradilan Tata Usaha Negara di Indonesia (Jakarta: Huma, 2010), hlm. 71.

37 Ibid.

38 Enrico Simanjuntak, Op.Cit., hlm. 92.
} 
(Persero) Distribusi Jawa Timur Area Sidoarjo No. 0737/DIS.00.03/AREASDA/2018, tanggal 1 Agustus 2018;

- Dalam Eksepsi: Mengabulkan eksepsi tergugat tentang Kompetensi Absolut;

- Dalam Pokok Perkara: Menyatakan gugatan Penggugat tidak dapat diterima dan membebankan Penggugat untuk membayar biaya perkara.

\section{Putusan Pengadilan Tata Usaha Negara} Bandung No. 74/G/2014/PTUN-BDG:

Kasus Posisi:

Para Pihak: PT. Bajatra (Penggugat) dan Executive Vice President Logistic PT. Kereta Api Indonesia (Persero) (Tergugat);

Objek Gugatan: Surat Keputusan Executive Vice President Logistic PT. Kereta Api Indonesia No. PL.105/V/6/KA-2014 tanggal 30 Mei 2014 perihal Blacklist PT. Bajatra selaku rekanan PT. Kereta Api Indonesia (Persero).

Pertimbangan hakim: bahwa surat keputusan obyek sengketa merupakan bentuk Keputusan Tata Usaha Negara yang terikat, artinya bahwa prosedur maupun substansi penerbitannya telah diatur oleh peraturan perundang-undangan.

Putusan:

- Dalam Penundaan: Mengabulkan permohonan penundaan Penggugat; Memerintahkan Tergugat untuk menunda pelaksanaan Keputusan Tata Usaha Negara berupa Surat Keputusan Executive Vice President Logistic PT. Kereta Api Indonesia No. PL.105/V/6/KA-2014

- Dalam Eksepsi: Menyatakan eksepsi Tergugat tidak diterima;

- Dalam Pokok Perkara: Mengabulkan gugat Penggugat seluruhnya; Menyatakan batal Surat Keputusan Executive Vice President Logistic PT. Kereta Api Indonesia No.
PL.105/V/6/KA-2014 dan mewajibkan Tergugat untuk mencabut Surat Keputusan Executive Vice President Logistic PT. Kereta Api Indonesia No. PL.105/V/6/KA-2014.

\section{Putusan Pengadilan Tata Usaha Negara Jakarta No. 02/G/2015/PTUN-JKT Kasus Posisi:}

Para Pihak: PT. Isis Megah Mandiri (Penggugat) dan Ketua Panitia Pengadaan Barang dan Jasa PT PLN Distribusi Jakarta Raya dan Tangerang Area Lenteng Agung (Tergugat);

Objek Gugatan: Surat No. 004/P2BJ(I)/A. LTA/2014 perihal Jawaban Somasi kedua dan terakhir, terkait penolakan keberatan penggugat atas pelelangan gagal dan pelelangan ulang pekerjaan jasa penarikan SKTM $20 \mathrm{Kv}$.

Pertimbangan hakim: bahwa oleh karena surat yang menjadi obyek sengketa terbukti bukan merupakan Keputusan Tata Usaha Negara, maka dengan demikian apa yang menjadi substansi eksepsi tergugat secara yuridis haruslah dinyatakan diterima, oleh karenanya terkait dengan kepentingan penggugat sebagaimana pertimbangan hukum di atas tentang kualitas penggugat, tidak perlu dipertimbangkan lagi.

Putusan:

- Dalam Eksepsi: Menerima eksepsi Tergugat tentang Kompetensi Absolut

- Dalam Pokok Perkara: Menyatakan gugatan Penggugat tidak diterima (Niet Onvankelijkeverklaard).

4. Putusan Pengadilan Tata Usaha Negara Jakarta No. 75/G/2011/PTUN-JKT

\section{Kasus Posisi:}

Para Pihak: Arifah Soeryono, Adnan Soeryono, dan MB. Almarini Soeryono 
(Penggugat) dan PT Bank Tabungan Negara (Persero) (Tergugat);

Objek Gugatan: Surat Keputusan Direksi PT. BTN (Persero), Tbk No. 64/DIR/2011 tanggal 18 Februari 2011 tentang Pembatalan Surat Keputusan Direksi No. 383/A Tanggal 7 Agustus 1965.

Pertimbangan hakim: bahwa salah satu unsur keputusan yang dapat menjadi objek sengketa tata usaha negara adalah tindakan tergugat harus berisi tindakan hukum tata usaha negara atau tindakan hukum yang mendasarkan pada ketentuan-ketentuan hukum publik. Oleh karena itu objek sengketa tidak memenuhi unsur tindakan hukum tata usaha negara dengan demikian bukanlah Keputusan Tata Usaha Negara sebagaimana dimaksud Pasal 1 angka 9 Undang-Undang No. 51 Tahun 2009.

Putusan:

- Dalam Eksepsi: Menerima eksepsi Tergugat tentang mengenai objek sengketa bukan objek gugatan Tata Usaha Negara;

- Dalam Pokok Sengketa: Menyatakan gugatan Penggugat tidak diterima.

5. Putusan Pengadilan Tata Usaha Negara Jakarta No. 196/G/2012/PTUN-JKT

Kasus Posisi:

Para Pihak: PT. Primakana Energy (Penggugat) dan Badan Usaha Bersama PT Bumi Siak Pusako - Pertamina Hulu (Tergugat);

Objek Gugatan: Surat Keputusan 244/VITL/2012 tanggal 13 Juni 2012 tentang Revisi Pengumuman Pemenang Lelang dan Surat Keputusan No. 3704/SCM-40/VII/12 tanggal

23 Juli 2012 tentang Sanksi Kategori Merah.

Putusan:

- Dalam Eksepsi: Menerima eksepsi Tergugat dan Tergugat II tentang gugatan Penggugat Kadaluarsa;
- Dalam Pokok Perkara: Menyatakan gugatan Penggugat tidak dapat diterima (Niet Onvankelijkeverklaard).

Berdasarkan contoh-contoh perkara tersebut di atas, maka tergambar belum adanya satu kesepahaman atau kesepakatan terkait Keputusan Tata Usaha Negara sebagai objek sengketa dan BUMN sebagai badan atau pejabat tata usaha negara.

Tiap-tiap hakim menafsirkan berbedabeda meskipun telah terdapat Surat Edaran Mahkamah Agung No. 4 Tahun 2016 dan Pedoman Khusus No. 052/Td.TUN/ III/1992. Apabila merujuk pada perkara yang memutuskan menolak bahwa keputusan direksi/manajer sebagai objek TUN dan BUMN sebagai badan atau pejabat TUN, maka hal-hal yang dijadikan alasan hakim adalah sebagai berikut:

a. Hakim menilai bahwa definisi Keputusan Tata Usaha Negara ketentuan Pasal 1 angka (9) UU No. 5 tahun 1986 sebagaimana telah diubah terakhir kali dengan UU No. 51 tahun 2009 tentang Perubahan Kedua Atas UU No. 5 Tahun 1986 merupakan ketentuan yang bersifat 'kumulatif', artinya setiap objek sengketa TUN harus memenuhi seluruh unsur-unsur dalam ketentuan tersebut dan apabila tidak terpenuhi salah satu unsur maka gugatan haruslah dinyatakan tidak dapat diterima.

b. Salah satu unsur keputusan yang dapat menjadi objek sengketa TUN adalah tindakan hukum tata usaha negara atau tindakan hukum yang mendasarkan pada ketentuan-ketentuan hukum publik.

Kemudian merujuk pada perkara yang memutuskan menerima bahwa keputusan direksi/manajer sebagai objek TUN dan BUMN sebagai badan atau pejabat TUN, maka 
hal-hal yang dijadikan alasan hakim adalah sebagai berikut:

a. Definisi Badan atau Pejabat Tata Usaha Negara dalam sengketa Tata Usaha Negara menganut kriteria yang lebih menitikberatkan pada fungsi suatu Badan atau Pejabat Tata Usaha Negara itu sendiri, artinya bahwa sepanjang suatu Badan atau Pejabat Tata Usaha Negara bertindak berdasarkan peraturan perundangundangan yang berlaku, danyang dikerjakan adalah urusan yang melaksanakan suatu kegiatan pemerintahan maka Badan atau Pejabat Tata Usaha Negara dimaksud telah memenuhi kriteria sebagaimana dimaksud Pasal 1 angka 8 jo. angka 12 UndangUndang Nomor 51 Tahun 2009 sehingga dapat dijadikan Tergugat dalam perkara a quo di Peradilan Tata Usaha Negara;

b. Obyek sengketa dan tindakan Tergugat dalam menerbitkan obyek sengketa adalah dalam rangka melaksanakan ketentuan peraturan perundang-undangan.

\section{Penutup}

Berdasarkan latar belakang masalah, rumusan masalah yang diajukan dan pembahasan tersebut di atas, maka dapat disimpulkan terkait Direksi BUMN merupakan Pejabat Tata Usaha Negara, maka berdasarkan definisi Badan atau Pejabat Tata Usaha Negara dalam UU No. 51 Tahun 2009 serta unsur yang lebih ditonjolkan dalam sengketa Tata Usaha Negara adalah unsur fungsi suatu Badan atau Pejabat Tata Usaha Negara serta unsur dari mana kewenangannya itu didapat, maka sepanjang suatu Direksi BUMN mendapatkan kewenangan berdasarkan peraturan perundang-undangan yang berlaku, dan kewenangan tersebut adalah urusan yang melaksanakan suatu kegiatan pemerintahan yang didapatkan melalui pelimpahan kewenangan, maka Direksi BUMN dimaksud telah memenuhi kriteria sebagaimana dimaksud Pasal 1 angka 8 dan Pasal 1 angka 12 Undang-Undang Nomor 51 Tahun 2009, sehingga dapat dijadikan Tergugat dalam di Peradilan Tata Usaha Negara.

Mengenai Keputusan Direksi BUMN adalah Keputusan Tata Usaha Negara, maka hal ini tergantung pada posisi direksi atau managerial BUMN ketika dia mengeluarkan keputusannya. Dalam posisinya sebagai pengemban tugas pemerintahan terkait Kewajiban Pelayanan Umum atau PSO dan juga urusan pemerintah lainnya, dimana BUMN mengembang sebagai 'kepanjangan tangan' Pemerintah, maka terhadap BUMN tersebut berlaku hukum administrasi, sehingga keputusan yang dikeluarkan data menjadi objek yang dapat digugat di pengadilan tata usaha negara. Tidak semua keputusan yang dikeluarkan oleh Direksi atau manajerial BUMN dapat dikategorikan sebagai keputusan tata usaha negara, dalam hal ini perlu dilihat dari tiap-tiap keputusan yang dikeluarkan apakah memenuhi karakteristik atau unsur dari suatu keputusan tata usaha negara.

Tidak semua BUMN atau Direksi BUMN dapat digenaralisir sebagai badan atau pejabat tata usaha negara, begitupula tidak semua keputusan dari direksi atau manajerial BUMN dianggap sebagai keputusan tata usaha negara. Hal ini dikarenakan entitas hukum BUMN memiliki dua sisi, yakni entitas hukum publik dan entitas hukum perdata, artinya meskipun BUMN adalah badan hukum perdata namun dalam skala ruang pengertian tertentu implikasi tindakan-tindakan hukumnya dalam bidang pelayanan publik 
menjadi sebuah isu hukum publik tersendiri. Sehingga apakah suatu keputusan direksi atau manajerial BUMN dapat digugat di Pengadilan Tata Usaha Negara seharusnya dilihat secara kasuitis.

\section{Daftar Pustaka}

\section{Buku}

Adhari, Agus, "Eksistensi BUMN sebagai Korporasi yang Dikuasai Negara," Jurnal Hukum Bisnis dan Investasi, Vol. 7 (1), 2015

Adriyani, Wuri, "Kedudukan Persero Dalam Hubungan Dengan Hukum Publik dan Hukum Privat", Disertasi, Fakultas Hukum Universitas Airlangga, 2009

Adriyani, Wuri, "Kedudukan Persero Dalam Hubungan Dengan Hukum Publik dan Hukum Privat", Disertasi, Fakultas Hukum Universitas Airlangga, 2009

Ali, Chaidir, dalam Ridwan Khairandy, "Konsepsi Kekayaan Negara Dipisahkan Dalam Perusahaan Perseroan," Jurnal Hukum Bisnis, Vol. 26, No.1, Tahun 2007

Anoraga, Panji, BUMN, Swasta dan Koperasi Tiga Pelaku Ekonomi (Semararang: Pustaka Jaya, 1994)

Atmadja, Arifin P. Soeria, Keuangan Publik dalam Perspektif Hukum (Jakarta: Rajawali Press, 2013)

Bedner, Adriaan W., Peradilan Tata Usaha Negara di Indonesia (Jakarta: Huma, 2010)

Ginting, Jamin, "Pengertian Merugikan Keuangan Negara dalam Tindak Pidana Korupsi", Jurnal Law Review Fakultas Hukum UPH, Vol. VI, No. 2, November 2006

Harahap, Yahya, Hukum Acara Perdata (Jakarta: Sinar Grafika, 2006)
HR, Ridwan, Hukum Administrasi Negara (Jakarta: Raja Grafindo, 2007)

Indroharto, Usaha Memahami Undang-Undang tentang Peradilan tata Usaha Negara (Jakarta: Pustaka Sinar Harapan, 2000)

Juliani, Henny, "Pertanggungjawaban Direksi Bumn Terhadap Perbuatan Yang Mengakibatkan Kerugian Keuangan Negara", Jurnal Masalah Masalah Hukum, Jilid 45 No. 4, Oktober 2016

Kementerian BUMN, Rencana Startegis Kementerian BUMN 2015-2019, diunduh dari www.bumn.go.id, diakses tanggal 17 November 2019

Khaerandy, Ridwan dan Camelia Malik, Good Corporate Governance (Yogyakarta: Total Media, 2007)

Manan, Bagir, "Penelitian Terapan di Bidang Hukum", (makalah, disampaikan pada Lokakarya Peranan Naskah Akademis Dalam Penyusunan Peraturan Perundang-undangan, BPHN, Jakarta, 9 - 11 November 1993)

Muhammad, Abdulkadir, Hukum dan Penelitian Hukum, (Bandung: Citra Aditya Bakti, 2004)

Simatupang, Dian Puji N., Paradoks Rasionalitas: Perluasan Ruang Lingkup Keuangan Negara dan Implikasinya Terhadap Kinerja Keuangan Pemerintah (Jakarta: Badan Penerbit FH UI, 2011)

Simanjuntak, Enrico, Hukum Acara Peradilan Tata Usaha Negara: Transformasi dan Refleksi (Jakarta: Sinar Grafika, 2018)

Supranto, J., Metode Penelitian Hukum dan Statistik, (Jakarta: Rineka Cipta, 2003)

Wignjosoebroto, Soetandyo, Ragam-ragam Penelitian Hukum, dalam Irianto, Sulistyowati dan Shidarta (Ed.). Metode Penelitian Hukum Konstelasi dan Refleksi, (Jakarta: Yayasan Pustaka Obor Jakarta, 2011) 